\title{
Anion Exchange Protein 3
}

National Cancer Institute

\section{Source}

National Cancer Institute. Anion Exchange Protein 3. NCI Thesaurus. Code C105069.

Anion exchange protein 3 (1232 aa, $\sim 136 \mathrm{kDa}$ ) is encoded by the human SLC4A3 gene.

This protein is involved in chloride/bicarbonate exchange in cardiac myocytes. 